\title{
Typical Gaseous Semi-Volatile Metals Adsorption by Meta-Kaolinite: A DFT Study
}

\author{
Xinye Wang ${ }^{1, * \mathbb{C}}$, Min Chen ${ }^{1,2}$, Changqi Liu ${ }^{2}{ }^{\mathbb{D}}$, Changsheng Bu ${ }^{1}$, Jubing Zhang ${ }^{1}$, \\ Chuanwen Zhao ${ }^{1, *}$ and Yaji Huang ${ }^{2}$ \\ 1 Jiangsu Provincial Key Laboratory of Materials Cycling and Pollution Control, School of Energy and \\ Mechanical Engineering, Nanjing Normal University, Nanjing 210042, China; chenminszx@163.com (M.C.); \\ csbu@njnu.edu.cn (C.B.); jubingzhang@njnu.edu.cn (J.Z.) \\ 2 Key Laboratory of Energy Thermal Conversion and Control of Ministry of Education, School of Energy and \\ Environment, Southeast University, Nanjing 210096, China; changqiliu@foxmail.com (C.L.); \\ heyyj@seu.edu.cn (Y.H.) \\ * Correspondence: xinye.wang@njnu.edu.cn (X.W.); cwzhao@njnu.edu.cn (C.Z.); \\ Tel.: +86-025-8548-1124 (X.W.)
}

Received: 25 August 2018; Accepted: 29 September 2018; Published: 30 September 2018

\begin{abstract}
Kaolinite can be used as in-furnace adsorbent to capture gaseous semi-volatile metals during combustion, incineration, or gasification processes for the purposes of toxic metals emission control, ash deposition/slagging/corrosion inhibition, ultrafine particulate matter emission control, and so on. In this work, the adsorptions of typical heavy metals ( $\mathrm{Pb}$ and $\mathrm{Cd}$ ) and typical alkali metals (Na and $\mathrm{K}$ ) by meta-kaolinite were investigated by the DFT calculation. The adsorption energies followed the sequence of $\mathrm{NaOH}-\mathrm{Si}$ surface $>\mathrm{KOH}$-Si surface $>\mathrm{PbO}-\mathrm{Al}$ surface $\approx \mathrm{CdO}$-Al surface $\approx$ $\mathrm{NaOH}-\mathrm{Al}$ surface $>\mathrm{KOH}-\mathrm{Al}$ surface $>\mathrm{NaCl}$-Al surface $\approx \mathrm{Na}-\mathrm{Si}$ surface $>\mathrm{Na}-\mathrm{Al}$ surface $>\mathrm{KCl}-\mathrm{Al}$ surface $>\mathrm{Pb}$-Al surface $>\mathrm{PbCl}_{2}-\mathrm{Al}$ surface $>\mathrm{CdCl}_{2}$-Al surface $\approx \mathrm{K}$-Si surface $\approx \mathrm{PbCl}-\mathrm{Al}$ surface $>\mathrm{K}$-Al surface $>\mathrm{CdCl}$-Al surface $>\mathrm{NaCl}-\mathrm{Si}$ surface $>\mathrm{KCl}-\mathrm{Si}$ surface $>\mathrm{Cd}$-Al surface. Si surface was found available to the adsorptions of $\mathrm{Na}, \mathrm{K}$, and their compounds, although it was invalid to the adsorptions of $\mathrm{Pb}, \mathrm{Cd}$, and their compounds. The interactions between adsorbates and surfaces were revealed. Furthermore, the discussion of combining with the experimental data was applied to the subject validity of calculation results and the effect of chlorine on adsorption and the effect of reducing atmosphere on adsorption.
\end{abstract}

Keywords: lead; cadmium; sodium; potassium; kaolinite; adsorption

\section{Introduction}

As a nonmetallic mineral, kaolinite is widely distributed in the world with large proven reserves. Its global production was 37 million tons in 2017 [1]. The primary uses of kaolinite are paper coating and filling, ceramics, paint, refractories, etc. due to its whiteness, brightness, glossiness, abrasiveness, viscosity, and fine particle size [2]. Besides the traditional uses, kaolinite can be used as in-furnace adsorbent to capture gaseous semi-volatile metals during combustion, incineration, or gasification processes for several purposes [3-5].

The first purpose is to control submicron heavy metals emission during coal, municipal solid waste, or sewage sludge combustion. Semi-volatile metals such as lead $(\mathrm{Pb})$ and Cadmium $(\mathrm{Cd})$ evaporate partially in furnace, and then condense in flue to be submicron aerosols $\left(\mathrm{PM}_{1}\right)$ which are difficult to remove efficiently via an electrostatic precipitator and bag filter [6-9]. Furthermore, activated carbon cannot remove these fine particles effectively either, although it is effective to remove elemental mercury which remains gaseous at low temperature [10]. The addition of supermicron 
kaolinite powder into the furnace can induce semi-volatile metals migration from submicron aerosols to supermicron particles $[5,11-13]$. Yao et al. added $5 \%$ of kaolinite in dried sludge, resulting in capture efficiencies of $50 \%$ and $40 \%$ for the control of submicron $\mathrm{Pb}$ and submicron $\mathrm{Cd}$ emissions, respectively, during the drop tube furnace combustion [11].

The second purpose is to lessen ash deposition, slagging and high-temperature corrosion during high potassium (K) biomass and high sodium $(\mathrm{Na})$ coal combustion or some co-combustion situations. These alkali metals volatilize in furnace, then react with ash particles to form low melting point phases rendering the particle surfaces sticky, or form sulfate condensing on heating surfaces directly $[3,14]$. A similar situation occurs in bed agglomeration, causing the defluidization of fluidized beds [15]. Aho added kaolinite in a $20 \mathrm{~kW}$ bubbling bed reactor with the fuel of biomass, and no coating of bed particles occurred at dosage $>0.3$ times the mass flow of ash [16].

The third purpose is to reduce particulate matter emissions during coal combustion, which contain high levels of alkali metals. $\mathrm{Na}$ and $\mathrm{K}$ have been proven to contribute greatly to ultrafine particulate matters formation by vaporization and condensation during the combustion of high $\mathrm{Na}$ coal and biomass, respectively $[17,18]$. Sun et al. added 3\% raw kaolinite and modified kaolinite into pulverized coal and reduced by about $16 \%$ and $40 \% \mathrm{PM}_{0.2}$ respectively during combustion in drop tube furnace [18]. The fourth purpose is to mitigate the blade corrosion in gas turbine of integrated gasification combined cycle (IGCC) and pressurized fluidized-bed combustors (PFBC) in combined-cycle power generation systems $[19,20]$.

The effect of kaolinite on metal capture has been investigated extensively, however, few studies focused on the capture mechanisms which has not been understood well yet [5,13]. Wendt et al. developed the aerosol size fractionation method (ASFM) to investigate the effect and mechanisms of $\mathrm{Pb} / \mathrm{Cd} / \mathrm{Na}$ capture by kaolinite powder with in-furnace injection process as industrial application background [21]. They described the kinetics of single metal capture and dual metals capture [12,22]. Shadman et al. developed thermogravimetric on-line detect method to investigate the effect and mechanisms of $\mathrm{Pb} / \mathrm{Cd} / \mathrm{Na}$ capture by kaolinite flake with high temperature fixed bed process as an industrial application background [23-25]. The resultant data included reaction product, saturated adsorption amount, and morphology changes [23-26].

Most previous research attempted to understand the capture mechanisms by experiments and obtained the results at macroscopic level. Some important phenomena and effects were found and interpreted [12]. However, the investigation of the capture mechanisms of heavy metals and alkali metals by kaolinite at the atomic level was just started. Since the capture occurs above $800{ }^{\circ} \mathrm{C}$ usually, it was difficult to conduct the atomic level observation of capture processes. The theoretical calculation based on density functional theory (DFT) was considered as an appropriate method to investigate these processes at an atomic level at the present stage. In the previous research, we calculated the adsorption of $\mathrm{Pb}$ and $\mathrm{Cd}$ on kaolinite surfaces, and revealed some information on adsorption sites, the adsorption energies and so on $[27,28]$. Recently, the calculation of Na adsorption was reported as well [29]. Many experimental phenomena were interpreted by the results from calculation, for example, the difference between $\mathrm{Pb}$ capture and $\mathrm{Cd}$ capture [27].

In this work, further investigation on the capture mechanisms was carried out. The calculation objects contained not only heavy metals ( $\mathrm{Pb}$ and $\mathrm{Cd}$ ) but also alkali metals ( $\mathrm{Na}$ and $\mathrm{K}$ ). Meta-kaolinite was considered as the adsorbent for the dehydroxylation of kaolinite caused by the flash calcination in the furnace [30]. This extensive comparison of different adsorption cases would give more interpretation and prediction to the results from experiment and application. Besides, a deeper understanding of adsorption mechanisms would help to figure out how to improve the capture ability of kaolinite. 


\section{Modeling and Computational Details}

\subsection{Adsorbates}

The species of heavy metals and alkali metals in furnace were difficult to detect by experiments, instead, they were predicted by thermodynamic equilibrium calculation based on Gibbs free energy minimization. It was found that the major species of $\mathrm{Pb}$ were monoxide, dichloride, monochloride, and single atoms in a waste incinerator while the major species of $\mathrm{Na}$ and $\mathrm{K}$ were considered as monochloride and hydroxide in the furnace [31,32]. These species were also involved in the combustion process and gasification process of coal or biomass [33-35]. In this work, the species of adsorbates involved in the calculation contained the single atoms of $\mathrm{Pb}, \mathrm{Cd}, \mathrm{Na}$, and $\mathrm{K}$; the oxides of $\mathrm{PbO}$ and $\mathrm{CdO}$; the hydroxides of $\mathrm{NaOH}$ and $\mathrm{KOH}$; the monochlorides of $\mathrm{PbCl}, \mathrm{CdCl}, \mathrm{NaCl}$, and $\mathrm{KCl}$; and the dichlorides of $\mathrm{PbCl}_{2}$ and $\mathrm{CdCl}_{2}$. The original structures of these adsorbates were downloaded from NIST Chemistry WebBook [36]. Then, these original structures were optimized in the lattice by DFT calculation. The computational details are described in Section 2.3. The optimized structures of adsorbates are shown in Figure 1.

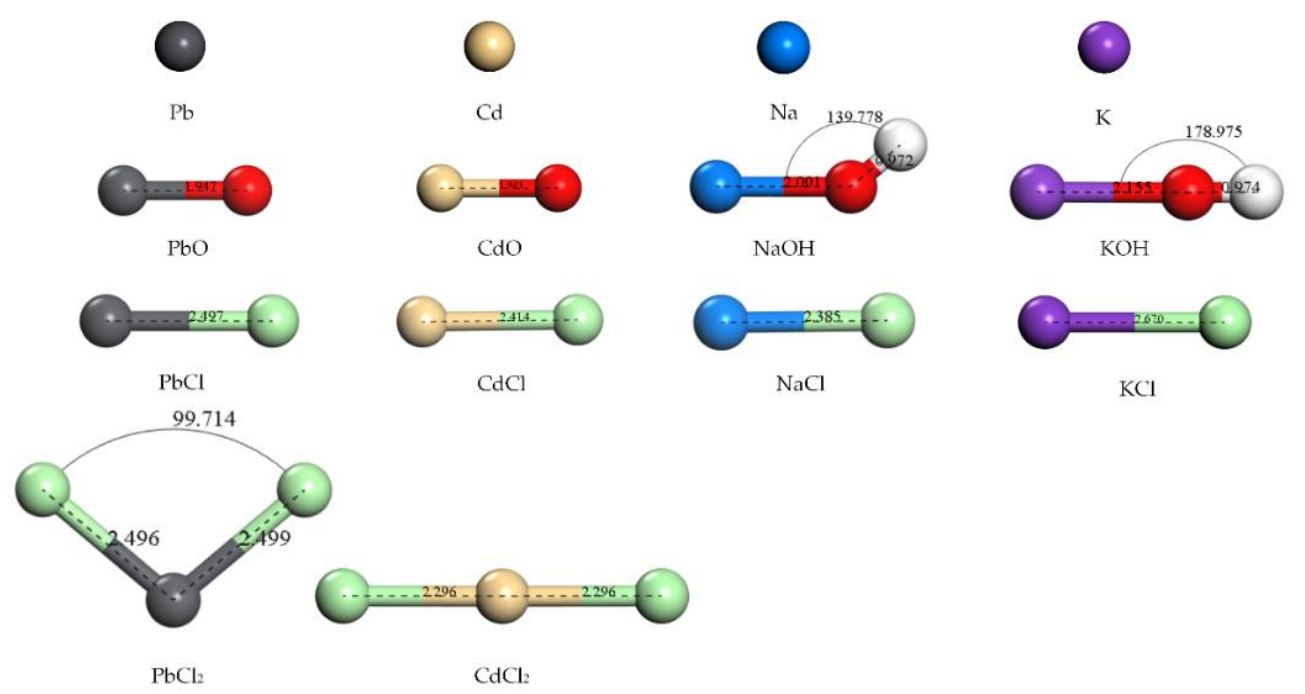

Figure 1. Geometric structures of adsorbates. The units of the bond length and bond angles are $\AA$ and ${ }^{\circ}$, respectively.

The structures of the diatomic molecules in Figure 1 are similar to each other, for example, the bond lengths of $\mathrm{PbO}$ and $\mathrm{CdO}$ are around $1.9 \AA$; and the bond lengths of $\mathrm{PbCl}, \mathrm{CdCl}, \mathrm{NaCl}$, and $\mathrm{KCl}$ are around $2.4 \AA$. However, the structures of the triatomic molecules in Figure 1 are different from each other, for example, $\mathrm{NaOH}$ and $\mathrm{PbCl}_{2}$ are broken line molecules while $\mathrm{KOH}$ and $\mathrm{CdCl}_{2}$ are linear molecules. The difference in structures should cause differences in adsorption characteristics.

\subsection{Adsorption Surfaces}

The raw kaolinite and calcined kaolinite were detected by scanning electron microscope (SEM) and the results are shown in Figure 2a,b. Both the raw kaolinite particle and calcined kaolinite were composed of the stacked flakes. The surface morphology of these flakes suggested that the layer structure remained well after the dehydroxylation induced by calcination. Therefore, the upper and lower surfaces of layers should dominate the total exposed surfaces, and the side surfaces were minority and negligible. We have investigated the adsorption ability of upper and lower surfaces which were described as aluminum (Al) surface $\left(\begin{array}{lll}0 & 0 & 1\end{array}\right)$ and silicon (Si) surface $\left(\begin{array}{lll}0 & 0 & \overline{1}\end{array}\right)$ [27,28]. Al surface has the abilities of $\mathrm{Pb}$ and $\mathrm{Cd}$ adsorption while an $\mathrm{Si}$ surface does not during the research on $\mathrm{Pb}$ and $\mathrm{Cd}$ adsorption $[27,28]$. However, it was unknown if Si surface was invalid in $\mathrm{Na}$ and $\mathrm{K}$ adsorption either. Consequently, both $\mathrm{Al}$ and Si surfaces were investigated as adsorption surfaces in this work. 

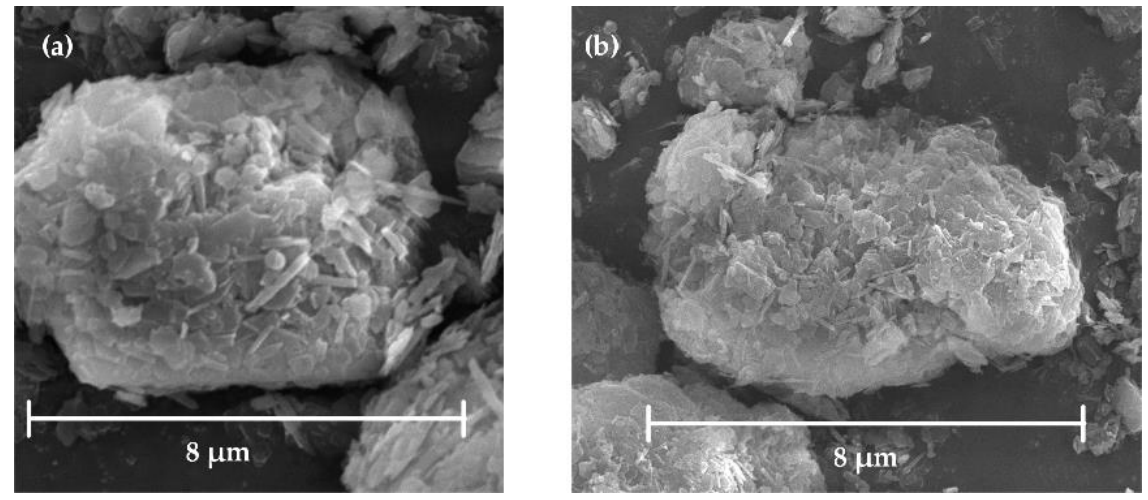

Figure 2. SEM micrographs of (a) raw kaolinite and (b) calcined kaolinite at $1000{ }^{\circ} \mathrm{C}$ for $30 \mathrm{~min}$.

The $\mathrm{Al} / \mathrm{Si}$ surface of meta-kaolinite was derived from the $\mathrm{Al} / \mathrm{Si}$ surface of kaolinite by the method of gradual dehydroxylation described before in [28]. Considering the weak interaction between layers of meta-kaolinite, only one layer was used as sorbent. The test of the layer number supported this decision that the difference between the adsorption energies of one-layer and two-layer structures was less than $2 \%$. The supercell size was $2 \times 1 \times 1$ and the vacuum thickness was $15 \AA$. The structures of meta-kaolinite surface are shown in Figure 3. No atoms were constrained during geometry optimization.
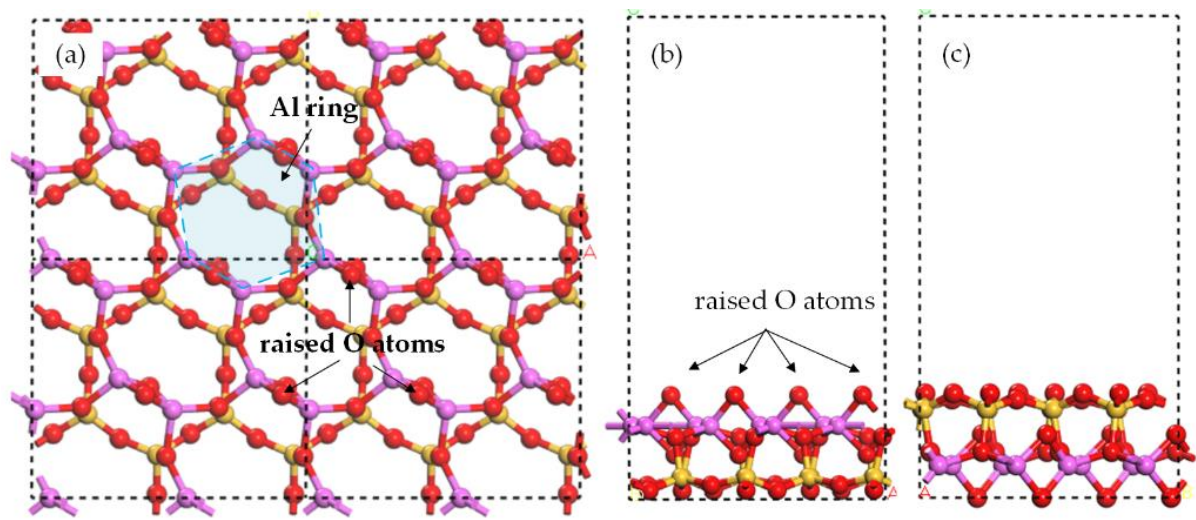

Figure 3. Optimized structure of $2 \times 2 \mathrm{Al}$ surface. (a) Top view of $\mathrm{Al}$ surface, (b) side view of $\mathrm{Al}$ surface, and (c) side view of Si surface. Yellow ball $=\mathrm{Si}$ atom, purple ball $=\mathrm{Al}$ atom, red ball $=\mathrm{O}$ atom, and white ball $=\mathrm{H}$ atom.

\subsection{Computational Methods}

The DFT calculations were on the basis of the plane-wave pseudopotential approach (CASTEP program) with the Vanderbilt ultra-soft pseudopotential, the generalized gradient approximation and the Perdew, Burke, and Ernzerhof functional (GGA-PBE) [37,38]. The geometry optimization algorithm was Broyden-Fletcher-Goldfarb-Shanno (BFGS) [39]. The plane-wave basis set energy cutoff was set at $380 \mathrm{eV}$. The convergence parameters were $5 \times 10^{-7} \mathrm{eV} /$ atom for self-consistent field (SCF) tolerance, $5 \times 10^{-6} \mathrm{eV} /$ atom for energy, $0.01 \mathrm{eV} / \AA$ for maximum force, $0.02 \mathrm{GPa}$ for maximum stress, and $5 \times 10^{-4} \AA$ for maximum displacement. The adsorption energy $\left(\Delta E_{\text {adsorption }}\right)$ was defined as Equation (1).

$$
\Delta E_{\text {adsorption }}=E_{\text {sorbate+sorbent }}-\left(E_{\text {sorbate }}+E_{\text {sorbent }}\right)
$$

where $E_{\text {sorbate+sorbent }}, E_{\text {sorbate}}$, and $E_{\text {sorbent }}$ are the energies of the sorbent with the adsorbed molecule, the sorbate, and bare sorbent, respectively. The charge density difference $(\Delta \rho)$ was defined as Equation (2).

$$
\Delta \rho=\rho_{\text {sorbate+sorbent }}-\left(\rho_{\text {sorbate }}+\rho_{\text {sorbent }}\right)
$$


where $\rho_{\text {sorbate+sorbent }}, \rho_{\text {sorbate, }}$ and $\rho_{\text {sorbent }}$ are the electron densities of the sorbent with the adsorbed molecule, the sorbate, and bare sorbent, respectively. Mulliken population was calculated for the analysis of charge transfer behavior [40].

\section{Results}

\subsection{Single Atom Adsorption on Al Surface}

The structures of single atom adsorption on Al surface are shown in Figure 4. The stable adsorption site with the highest adsorption energy was close to the center of $\mathrm{Al}$ ring. The $\mathrm{Pb}$ atom was close to two raised oxygen $(\mathrm{O})$ atoms and one $\mathrm{Al}$ atom in $\mathrm{Al}$ surface. The position of $\mathrm{Cd}$ atom was similar to that of $\mathrm{Pb}$ atom, however, the $\mathrm{Cd}$ atom was closer to the $\mathrm{Al}$ atom and farther away from two raised $\mathrm{O}$ atoms. The $\mathrm{Na}$ atom and the $\mathrm{K}$ atom were almost on the center of $\mathrm{Al}$ ring. Compared with the $\mathrm{K}$ atom, the $\mathrm{Na}$ atom seemed to have stronger attraction to the two raised $\mathrm{O}$ atoms, because the distances of $\mathrm{Na}-\mathrm{O}$ (around 2.4 $\AA$ ) were shorter than that of K-O (around $2.6 \AA$ ).
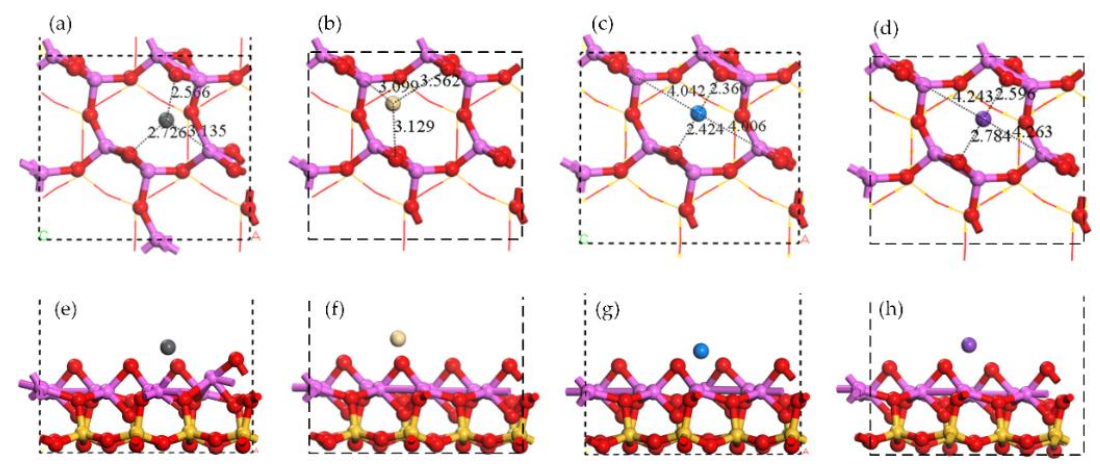

Figure 4. Optimized structures of single atom adsorptions on Al surface. Top view of (a) Pb adsorption, (b) Cd adsorption, (c) Na adsorption, and (d) K adsorption. Side view of (e) Pb adsorption, (f) $\mathrm{Cd}$ adsorption, (g) Na adsorption, and (h) K adsorption.

The distributions of electron density and electron density difference are shown in Figure 5. The interaction between the $\mathrm{Pb}$ atom and the $\mathrm{Al}$ atom was obvious, while the interaction between the $\mathrm{Cd}$ atom and $\mathrm{Al}$ atom existed as well but was weaker. No similar interaction was found in $\mathrm{Na}$ adsorption or $\mathrm{K}$ adsorption. The charge accumulation between a single atom and two raised $\mathrm{O}$ atoms was close to the $\mathrm{Pb}$ atom but was away from the $\mathrm{Na}$ atom and the $\mathrm{K}$ atom. It indicated that $\mathrm{Na}-\mathrm{O}$ has a stronger ionic bond characteristic than $\mathrm{Pb}-\mathrm{O}$ which exhibited a covalent bond characteristic [41]. The interaction between the $\mathrm{K}$ atom and two raised $\mathrm{O}$ atoms was weak and no interaction was found between the $\mathrm{Cd}$ atom and two raised $\mathrm{O}$ atoms.
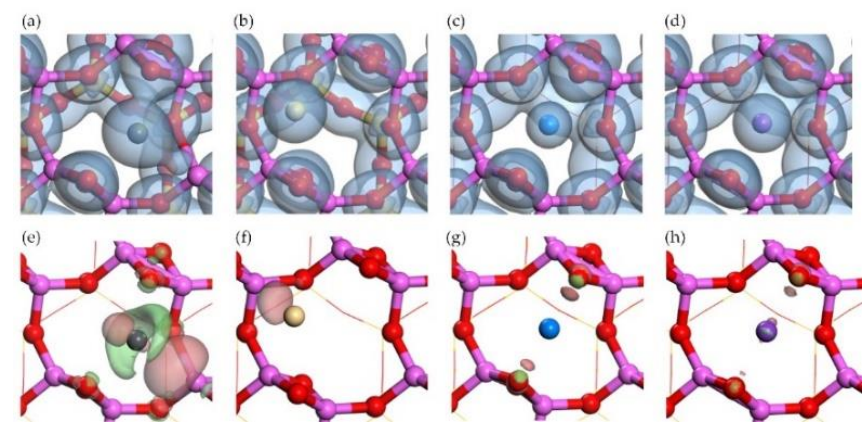

Figure 5. Electron density of single atom adsorptions on $\mathrm{Al}$ surface: top view of (a) Pb adsorption, (b) Cd adsorption, (c) Na adsorption, and (d) K adsorption. Electron density difference of single atom adsorptions on $\mathrm{Al}$ surface: top view of (e) Pb adsorption, (f) Cd adsorption, (g) Na adsorption, and (h) $\mathrm{K}$ adsorption. Pink means charge accumulation while green means charge depletion. 
The adsorption energies and the Mulliken charge change were listed in Table 1. The adsorption energies followed the sequence of $\mathrm{Na}>\mathrm{Pb}>\mathrm{K}>\mathrm{Cd}$. The first three adsorptions $(\mathrm{Na}, \mathrm{Pb}$, and $\mathrm{K}$ ) were chemical while the last $(\mathrm{Cd})$ was physical judging from the adsorption energies. The Mulliken charge changes show the similar sequence but did not coincide completely. It is noteworthy that the interaction between single atom and two raised $\mathrm{O}$ atoms in $\mathrm{Al}$ surface followed the same sequence to adsorption energies. It presented in the distance and charge accumulation described above. For example, $d_{\mathrm{Na}-\mathrm{O}}=2.39 \AA<d_{\mathrm{Pb}-\mathrm{O}}=2.65 \approx d_{\mathrm{K}-\mathrm{O}}=2.69 \AA<d_{\mathrm{Cd}-\mathrm{O}}=3.35 \AA$, where $d$ indicates the average distance between the metal atom and two raised $\mathrm{O}$ atoms. Therefore, the attraction from the raised $\mathrm{O}$ atoms was considered to play the dominant role in single atom adsorption on $\mathrm{Al}$ surface while the attraction from $\mathrm{Al}$ atoms was less important.

Table 1. Mulliken charge changes and adsorption energies of 14 species adsorptions on $\mathrm{Al}$ surface.

\begin{tabular}{|c|c|c|c|c|c|}
\hline \multirow{2}{*}{$\begin{array}{c}\text { Sorbate } \\
\mathrm{Pb}\end{array}$} & \multicolumn{4}{|c|}{ Mulliken Charge Change ${ }^{1}$ (e) } & \multirow{2}{*}{$\begin{array}{c}\begin{array}{c}\text { Adsorption Energy } \\
\text { (kJ/mol) }\end{array} \\
-224\end{array}$} \\
\hline & $\mathrm{Pb}:+0.49$ & & & Total: +0.49 & \\
\hline $\mathrm{Cd}$ & $\mathrm{Cd}:+0.22$ & & & Total: +0.22 & -36 \\
\hline $\mathrm{Na}$ & $\mathrm{Na}:+0.70$ & & & Total: +0.70 & -243 \\
\hline K & $\mathrm{K}:+0.79$ & & & Total: +0.79 & -168 \\
\hline $\mathrm{PbO}$ & $\mathrm{Pb}:+0.42$ & $\mathrm{O}:-0.40$ & & Total: +0.02 & -476 \\
\hline $\mathrm{CdO}$ & $\mathrm{Cd}:+0.43$ & $\mathrm{O}:-0.35$ & & Total: +0.08 & -471 \\
\hline $\mathrm{NaOH}$ & $\mathrm{Na}:+0.14$ & $\mathrm{O}:+0.18$ & $\mathrm{H}:+0.02$ & Total: +0.34 & -474 \\
\hline $\mathrm{KOH}$ & $\mathrm{K}:+0.14$ & $\mathrm{O}:+0.30$ & $\mathrm{H}:+0.01$ & Total: +0.45 & -368 \\
\hline $\mathrm{PbCl}$ & $\mathrm{Pb}:+0.18$ & $\mathrm{Cl}:-0.02$ & & Total: +0.16 & -196 \\
\hline $\mathrm{CdCl}$ & $\mathrm{Cd}:+0.10$ & $\mathrm{Cl}:+0.02$ & & Total: +0.12 & -149 \\
\hline $\mathrm{NaCl}$ & $\mathrm{Na}:+0.13$ & $\mathrm{Cl}:+0.25$ & & Total: +0.38 & -300 \\
\hline $\mathrm{KCl}$ & $\mathrm{K}:+0.15$ & $\mathrm{Cl}:+0.39$ & & Total: +0.54 & -239 \\
\hline $\mathrm{PbCl}_{2}$ & $\mathrm{~Pb}:+0.1$ & Cl1: 0 & $\mathrm{Cl} 2: 0$ & Total: +0.10 & -209 \\
\hline $\mathrm{CdCl}_{2}$ & $\mathrm{Cd}:+0.05$ & Cl1: +0.06 & $\mathrm{Cl} 2:+0.06$ & Total: +0.16 & -199 \\
\hline
\end{tabular}

${ }^{1}$ Mulliken charge change is defined as the charge difference after and before adsorption. + indicates electron donation while - indicates electron acceptance.

\subsection{Oxide and Hydroxide Adsorption on Al Surface}

On the $\mathrm{Al}$ surface, the $\mathrm{Al}$ ring consists of six sides of $\mathrm{Al}-\mathrm{O}-\mathrm{Al}$. Two raised $\mathrm{O}$ atoms are on the opposite sides as shown in Figure 3. The adsorption of $\mathrm{PbO}$ molecule caused the move of one raised $\mathrm{O}$ atom to the side next to its original site and far away from the $\mathrm{O}$ atom in $\mathrm{PbO}$, as shown in Figure 6a. In the adsorption structure, the $\mathrm{Pb}$ atom was in the center of $\mathrm{Al}$ ring and the $\mathrm{O}$ atom in $\mathrm{PbO}$ seemed to be the third raised $\mathrm{O}$ atom in $\mathrm{Al}$ ring, forming a new symmetrical structure. The lengths of two newly formed $\mathrm{Al}-\mathrm{O}$ bonds (the $\mathrm{O}$ atom was from $\mathrm{PbO}$ ) were $1.77 \AA$ and $1.97 \AA$, close to the original bond length of $1.76 \AA$ in $\mathrm{Al}$ surface. The $\mathrm{PbO}$ molecule was elongated so that the distances between the $\mathrm{Pb}$ atom and three raised $\mathrm{O}$ atoms were all around $2.3 \AA$, resulting in the center site of $\mathrm{Pb}$ atom.
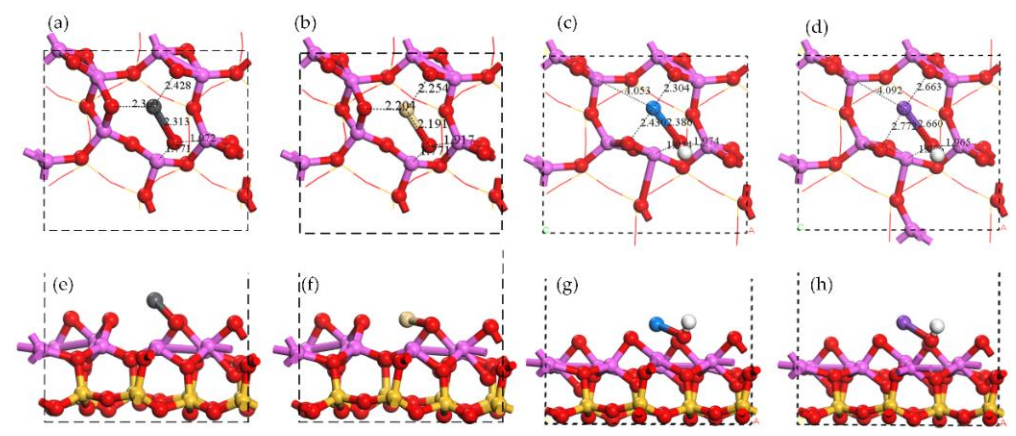

Figure 6. Optimized structures of oxide molecule adsorptions and hydroxide molecule adsorptions on $\mathrm{Al}$ surface. Top view of (a) PbO adsorption, (b) CdO adsorption, (c) $\mathrm{NaOH}$ adsorption, and (d) $\mathrm{KOH}$ adsorption. Side view of (e) $\mathrm{PbO}$ adsorption, (f) $\mathrm{CdO}$ adsorption, (g) $\mathrm{NaOH}$ adsorption, and (h) $\mathrm{KOH}$ adsorption. 
The adsorption structure of $\mathrm{CdO}$ molecule was pretty similar to that of $\mathrm{PbO}$ molecule, as shown in Figure $6 \mathrm{~b}$. However, the structures of $\mathrm{NaOH}$ adsorption and $\mathrm{KOH}$ adsorption were different. Although the position of the $\mathrm{Na}$ atom was also in the center of $\mathrm{Al}$ ring, and the $\mathrm{O}$ atom in $\mathrm{NaOH}$ seemed to bond with the $\mathrm{Al}$ atoms, the raised $\mathrm{O}$ atom originally in $\mathrm{Al}$ surface did not move to other sites, as shown in Figure 6c. Therefore, the adsorption structure of the $\mathrm{NaOH}$ molecule was not as symmetrical as that of $\mathrm{PbO}$ molecule. Because of the attractions from the surface to the $\mathrm{O}$ atom from $\mathrm{NaOH}$, the bond length of $\mathrm{Na}-\mathrm{O}$ in $\mathrm{NaOH}$ was elongated as well. The structure of the $\mathrm{KOH}$ molecule is linear before adsorption; however, it turned into a broken line type like the $\mathrm{NaOH}$ molecule after adsorption.

The electron density distribution shown in Figure 7a described the overlap of electron density between the $\mathrm{Pb}$ atom and three raised $\mathrm{O}$ atoms, one of which was derived from $\mathrm{PbO}$. The symmetric shape of isosurface suggested that the $\mathrm{O}$ atom derived from $\mathrm{PbO}$ was integrated into $\mathrm{Al}$ surface so well that it exhibited few differences from two original raised $\mathrm{O}$ atoms. Moreover, this overlap indicated the covalent characteristic of three $\mathrm{Pb}-\mathrm{O}$ bonds, which were supported by the charge accumulation between the $\mathrm{Pb}$ atom and two raised $\mathrm{O}$ atoms in Figure 7e [41]. No overlap of electron density between the $\mathrm{O}$ atom derived from $\mathrm{PbO}$ and $\mathrm{Al}$ atoms and no charge accumulation between them, but the charge accumulation around the $\mathrm{O}$ atom derived from $\mathrm{PbO}$. It indicated the ionic characteristic of an $\mathrm{O}-\mathrm{Al}$ bond, same as the $\mathrm{Al}_{2} \mathrm{O}_{3}$ crystal. The Mulliken charge changes in Table 1 indicated the charge acceptance of the $\mathrm{O}$ atom derived from $\mathrm{PbO}$ as well. The same characteristics were found in $\mathrm{CdO}$ adsorption structure by the analysis of Figure $7 \mathrm{~b}$,f. However, in $\mathrm{NaOH}$ adsorption and $\mathrm{KOH}$ adsorption, no overlap of electron density between $\mathrm{Na}-\mathrm{O}$ or $\mathrm{K}-\mathrm{O}$ were found and the charge accumulated around raised $\mathrm{O}$ atoms as shown in Figure $7 \mathrm{~g}$, $\mathrm{h}$, indicating the ionic characteristics of $\mathrm{Na}-\mathrm{O}$ bond and $\mathrm{K}-\mathrm{O}$ bond. Besides that, the $\mathrm{O}-\mathrm{H}$ derived from $\mathrm{NaOH}$ or $\mathrm{KOH}$ was considered as the charge donator to $\mathrm{Al}$ surface according to the analysis of electron density difference and the Mulliken charge change. Overall, the interactions between the $\mathrm{O}$ atoms derived from sorbates and the $\mathrm{Al}$ atoms were stronger than the interactions between the metal atoms derived from sorbates and the raised $\mathrm{O}$ atoms.
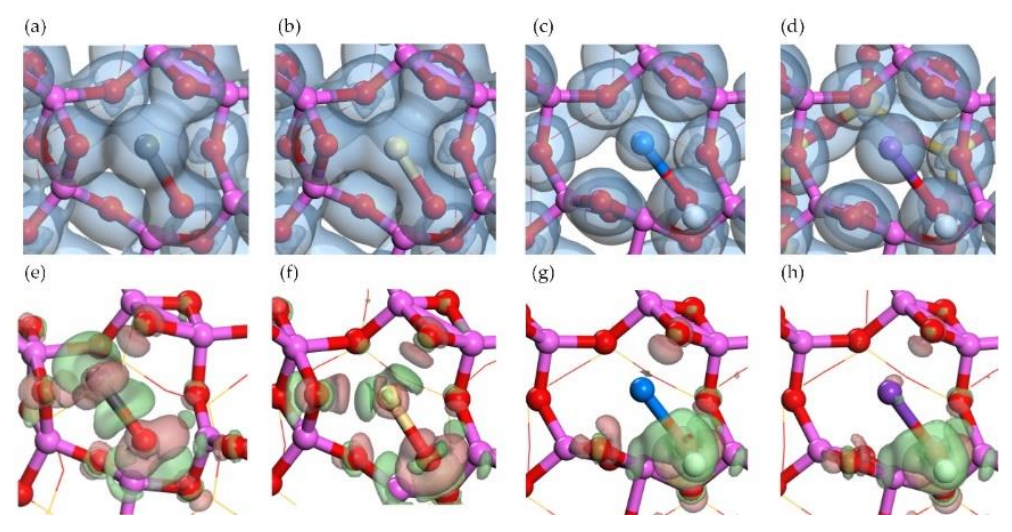

Figure 7. Electron density of oxide molecule adsorptions and hydroxide molecule adsorptions on Al surface: top view of (a) $\mathrm{PbO}$ adsorption, (b) $\mathrm{CdO}$ adsorption, (c) $\mathrm{NaOH}$ adsorption, and (d) $\mathrm{KOH}$ adsorption. Electron density difference of oxide molecule adsorptions and hydroxide molecule adsorptions on $\mathrm{Al}$ surface: top view of (e) $\mathrm{PbO}$ adsorption, (f) $\mathrm{CdO}$ adsorption, (g) $\mathrm{NaOH}$ adsorption, and (h) $\mathrm{KOH}$ adsorption.

The adsorption energies of $\mathrm{PbO}, \mathrm{CdO}, \mathrm{NaOH}$, and $\mathrm{KOH}$ shown in Table 1 were much higher than that of single atoms and followed the sequence of $\mathrm{PbO} \approx \mathrm{CdO} \approx \mathrm{NaOH}>\mathrm{KOH}$. These adsorptions were all chemical for the adsorption energies higher than $-350 \mathrm{~kJ} / \mathrm{mol}$. Although the cations of four compounds were different, their adsorption energies were very close. It should be due to the strong attraction between the $\mathrm{O}$ atom and the $\mathrm{Al}$ atoms in the adsorption structure. The interaction between the metal atom and the raised $\mathrm{O}$ atoms did not dominate the adsorption. 


\subsection{Chloride Adsorption on Al Surface}

The adsorption structures of monochlorides are shown in Figure 8. In $\mathrm{PbCl}$ adsorption structure the $\mathrm{Pb}$ atom was on the center of $\mathrm{Al}$ ring while the $\mathrm{Cl}$ atom was close to two $\mathrm{Al}$ atoms. The similar structure was shown in the adsorption of $\mathrm{CdCl}, \mathrm{NaCl}$, and $\mathrm{KCl}$. The difference was in the average distance of $\mathrm{Cl}-\mathrm{Al}$ that $d_{\mathrm{K}-\mathrm{Cl}}=2.41 \approx d_{\mathrm{Na}-\mathrm{Cl}}=2.49 \AA<d_{\mathrm{Cd}-\mathrm{Cl}}=2.74 \AA \approx d_{\mathrm{Pb}-\mathrm{Cl}}=2.82 \AA$. All four monochloride molecules were elongated for adsorption.
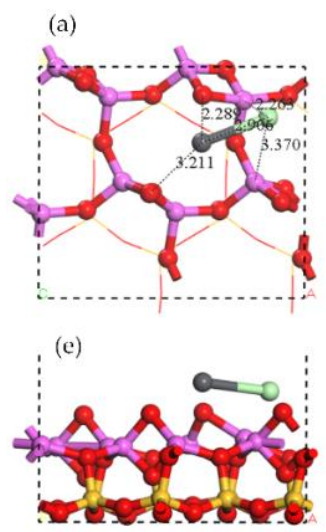
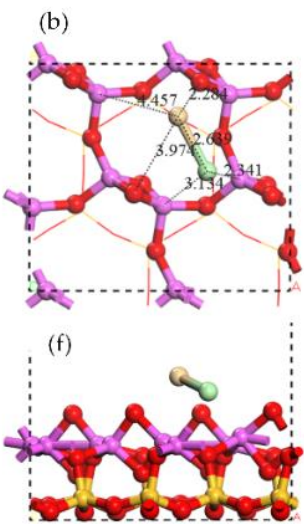
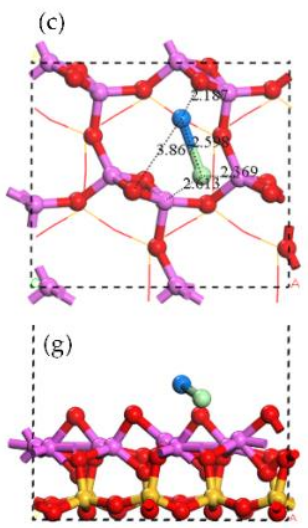
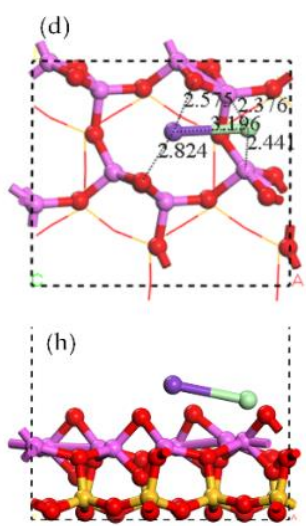

Figure 8. Optimized structures of monochloride molecule adsorptions on Al surface. Top view of (a) $\mathrm{PbCl}$ adsorption, (b) $\mathrm{CdCl}$ adsorption, (c) $\mathrm{NaCl}$ adsorption, and (d) $\mathrm{KCl}$ adsorption. Side view of (e) $\mathrm{PbCl}$ adsorption, (f) $\mathrm{CdCl}$ adsorption, (g) $\mathrm{NaCl}$ adsorption, and (h) $\mathrm{KCl}$ adsorption.

The distribution of electron density and electron density difference of monochloride adsorptions are shown in Figure 9. The charge accumulation was found between the $\mathrm{Cl}$ atom and the $\mathrm{Al}$ atoms, indicating the covalent characteristic of $\mathrm{Cl}-\mathrm{Al}$ in all four adsorption structures. There was obvious charge accumulation between the $\mathrm{Pb}$ atom and the $\mathrm{Al}$ atom in $\mathrm{PbCl}$ adsorption, the same as that in $\mathrm{Pb}$ atom adsorption. Moreover, no such interaction was found in the adsorption of other monochlorides, the same as the in single adsorption as well. The Mulliken charge changes of the $\mathrm{Cl}$ atom in $\mathrm{PbCl}$ adsorption and $\mathrm{CdCl}$ adsorption were much lower than that in $\mathrm{NaCl}$ adsorption and $\mathrm{KCl}$ adsorption. Compared with the interaction between the $\mathrm{Cl}$ atom and the $\mathrm{Al}$ atoms, the interaction between metal atom and the raised $\mathrm{O}$ atom was insignificant. The adsorption energies sequence of $\mathrm{NaCl}>\mathrm{KCl}>\mathrm{PbCl}$ $>\mathrm{CdCl}$ shown in Table 1 indicated that the $\mathrm{Cl}$ atom bonding with $\mathrm{Na}$ and $\mathrm{K}$ was more active than that bonding with $\mathrm{Pb}$ and $\mathrm{Cd}$.
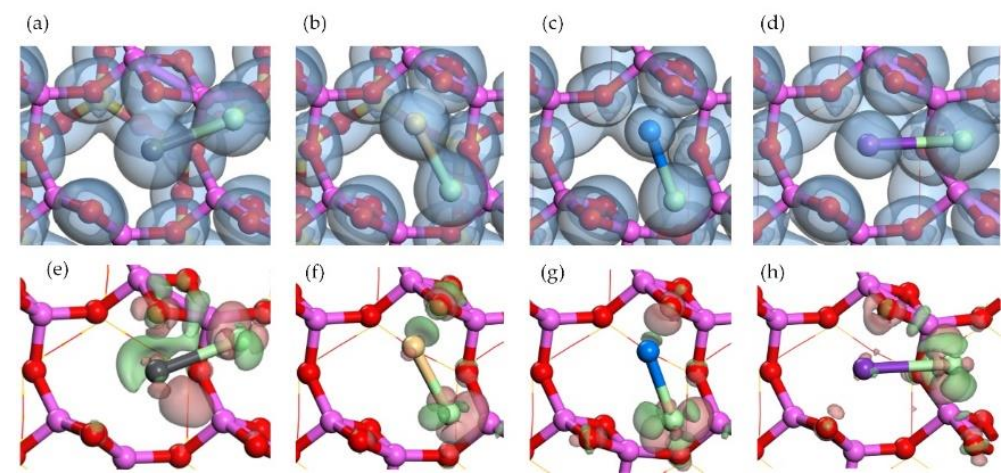

Figure 9. Electron density of monochloride molecule adsorptions on $\mathrm{Al}$ surface: top view of (a) $\mathrm{PbCl}$ adsorption, (b) $\mathrm{CdCl}$ adsorption, (c) $\mathrm{NaCl}$ adsorption, and (d) $\mathrm{KCl}$ adsorption. Electron density difference of monochloride molecule adsorptions on $\mathrm{Al}$ surface: top view of (e) $\mathrm{PbCl}$ adsorption, (f) $\mathrm{CdCl}$ adsorption, (g) $\mathrm{NaCl}$ adsorption, and (h) $\mathrm{KCl}$ adsorption. 
The dichloride adsorption structures are shown in Figure $10 \mathrm{a}-\mathrm{d}$. The $\mathrm{PbCl}_{2}$ molecule has the shape of a broken line. In Figure $10 \mathrm{a}, \mathrm{c}$, the $\mathrm{Cl}$ atom was above $\mathrm{Al}-\mathrm{O}-\mathrm{Al}$ and was close to one of $\mathrm{Al}$ atom. The $\mathrm{Pb}$ atom was close to one raised $\mathrm{O}$ atom. The $\mathrm{CdCl}_{2}$ molecule has the shape of straight line. In Figure $10 \mathrm{~b}, \mathrm{~d}$, the positions of $\mathrm{Cl}$ atom were similar to that of $\mathrm{PbCl}_{2}$ adsorption, but was closer one of $\mathrm{Al}$ atom in $\mathrm{Al}-\mathrm{O}-\mathrm{Al}$. The $\mathrm{Cd}$ atom was almost on the center of the $\mathrm{Al}$ ring. The distribution of electron density and electron density difference of dichloride adsorption structures are shown in Figure 10e- $\mathrm{h}$. The overlap of electron density between the $\mathrm{Pb}$ atom and one raised $\mathrm{O}$ atom and the charge accumulation between the $\mathrm{Cl}$ atoms and the $\mathrm{Al}$ atoms indicated the covalent characteristic of $\mathrm{Pb}-\mathrm{O}$ bond and $\mathrm{Cl}-\mathrm{Al}$ bond. The similar bond characteristics were shown in $\mathrm{CdCl}_{2}$ adsorption structure. According to Table 1, the adsorption energies of $\mathrm{PbCl}_{2}(-209 \mathrm{~kJ} / \mathrm{mol})$ and $\mathrm{CdCl}_{2}$ $(-199 \mathrm{~kJ} / \mathrm{mol})$ increased with the additional $\mathrm{Cl}$ atoms compared with those of $\mathrm{PbCl}(-196 \mathrm{~kJ} / \mathrm{mol})$ and $\mathrm{CdCl}(-149 \mathrm{~kJ} / \mathrm{mol})$, however, these increases were limited.
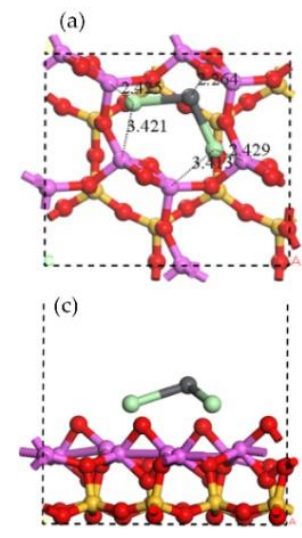
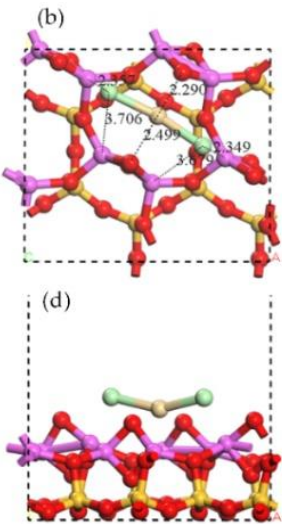
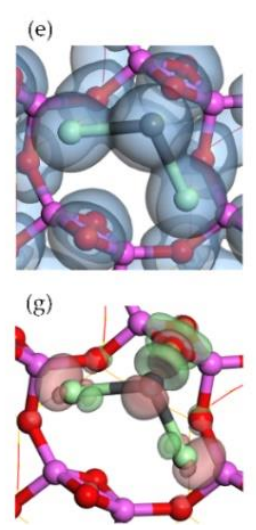
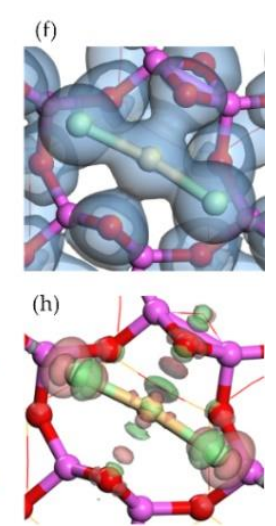

Figure 10. Optimized structures of dichloride molecule adsorptions on $\mathrm{Al}$ surface. Top view of the structures of (a) $\mathrm{PbCl}_{2}$ adsorption and (b) $\mathrm{CdCl}_{2}$ adsorption. Side view of the structures of (c) $\mathrm{PbCl}_{2}$ adsorption and (d) $\mathrm{CdCl}_{2}$ adsorption. Electron density difference of dichloride adsorption structures on $\mathrm{Al}$ surface: top view of (e) $\mathrm{PbCl}_{2}$ adsorption, (f) $\mathrm{CdCl}_{2}$ adsorption. Side view of (g) $\mathrm{PbCl}_{2}$ adsorption, and (h) $\mathrm{CdCl}_{2}$ adsorption.

\subsection{Alkali Metal Adsorption on Si Surface}

Si surface was considered invalid to the adsorption of $\mathrm{Pb}, \mathrm{Cd}$, and their compounds [27,28]. However, it showed ability to adsorb $\mathrm{Na}, \mathrm{K}$, and their compounds. The adsorption structures of single atoms, hydroxide, and monochloride of $\mathrm{Na}$ and $\mathrm{K}$ on $\mathrm{Si}$ surface are shown in Figure 11. The Na atom and $\mathrm{K}$ atom were considered to be adsorbed on the center of $\mathrm{Si}$ ring other than on the top of $\mathrm{O}$ atom according to the comparison of adsorption energies. The charge transfers after the adsorption of the $\mathrm{Na}$ atom and the K atom on Si surface were higher than that on Al surface, as shown in Tables 1 and 2. So were the adsorption energies, which indicated that the adsorptions of $\mathrm{Na}$ atom and $\mathrm{K}$ atom were chemical. The charge accumulation was found not only between the adsorbed atom and the $\mathrm{O}$ atoms from $\mathrm{Si}$ ring but also between the adsorbed atom and one $\mathrm{O}$ atom from $\mathrm{Al}$ ring, as shown in Figure 12a,b,g,h. The adsorptions of $\mathrm{NaOH}$ and $\mathrm{KOH}$ caused the decomposition of metal atom and $\mathrm{OH}$. The adsorption structures of $\mathrm{NaOH}$ and $\mathrm{KOH}$ in Figure 12c, d indicated that the alkali atom remained on the center of $\mathrm{Si}$ ring while $\mathrm{OH}$ combined with the $\mathrm{Si}$ atom causing the broken of Si-O-Al. The adsorption energies of $\mathrm{NaOH}$ and $\mathrm{KOH}$ on $\mathrm{Si}$ surface were higher than $-600 \mathrm{~kJ} / \mathrm{mol}$, the highest in all cases. The distribution of electron density difference in Figure 12i,j revealed the strong interaction between $\mathrm{OH}$ and the $\mathrm{Si}$ atom, which was considered as the reason for the high adsorption energies of $\mathrm{NaOH}$ and $\mathrm{KOH}$. According to the adsorption energy in Table 2, $\mathrm{NaCl}$ was adsorbed chemically while $\mathrm{KCl}$ was physically. The distribution of electron density difference in Figure 12k,l indicated that the $\mathrm{Na}$ atom had interaction with the $\mathrm{O}$ atoms from Si ring and $\mathrm{Al}$ ring, the $\mathrm{K}$ atom had no obvious interaction with surface and the $\mathrm{Cl}$ atom had no interaction with surface. Therefore, the attraction 
between $\mathrm{NaCl} / \mathrm{KCl}$ and $\mathrm{Si}$ surface was due to the interaction between the $\mathrm{Na} / \mathrm{K}$ atom and surface. The $\mathrm{Cl}$ atom in $\mathrm{NaCl}$ and $\mathrm{KCl}$ inhibited the adsorption on Si surface, however, it was in favor of the adsorption on Al surface. The adsorption energies in Table 2 were higher than those obtained by Zhang et al. [29].

(a)

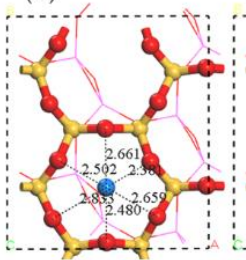

(g) (b)

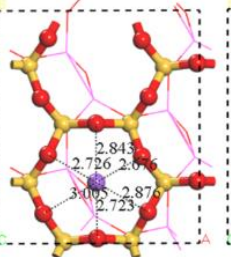

(c)

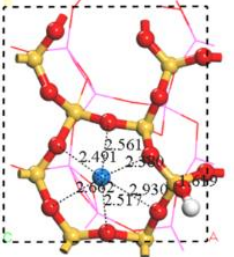

(i) (d)

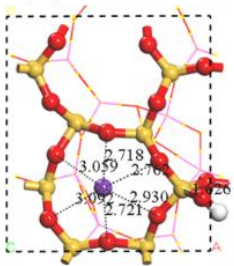

(e)

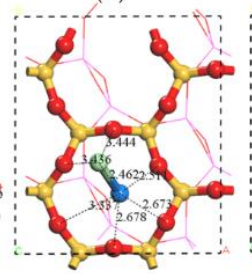

(k) (f)

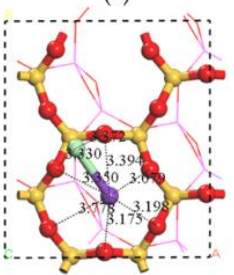

(1)

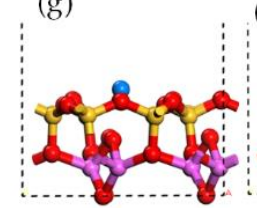

(h)

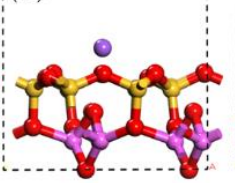

(j)
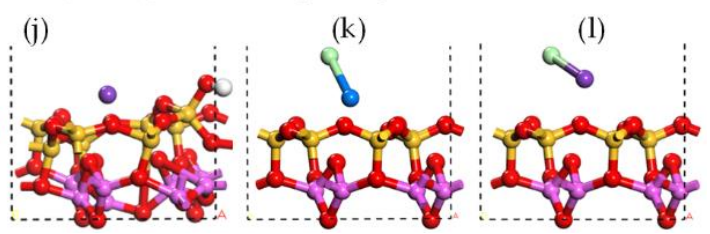

Figure 11. Optimized structures of alkali metal adsorptions on Si surface. Top view of the structures of (a) Na atom adsorption, (b) $\mathrm{K}$ atom adsorption, (c) $\mathrm{NaOH}$ adsorption, (d) $\mathrm{KOH}$ adsorption, (e) $\mathrm{NaCl}$ adsorption, and (f) $\mathrm{KCl}$ adsorption. Side view of the structures of (g) Na atom adsorption, (h) K atom adsorption, (i) $\mathrm{NaOH}$ adsorption, (j) $\mathrm{KOH}$ adsorption, (k) $\mathrm{NaCl}$ adsorption, and (1) $\mathrm{KCl}$ adsorption.

Table 2. Mulliken charge changes and adsorption energies of six species adsorption on Si surface.

\begin{tabular}{cccccc}
\hline Sorbate & \multicolumn{3}{c}{ Mulliken Charge Change (e) } & & $\begin{array}{c}\text { Adsorption Energy } \\
\mathbf{( k J / m o l )}\end{array}$ \\
\hline $\mathrm{Na}$ & $\mathrm{Na}:+1.09$ & & & Total: +1.09 & -295 \\
$\mathrm{~K}$ & $\mathrm{~K}:+1.17$ & & Total: +1.17 & -197 \\
\hline $\mathrm{NaOH}$ & $\mathrm{Na}:+0.42$ & $\mathrm{O}:+0.15$ & $\mathrm{H}:+0.11$ & Total: +0.68 & -742 \\
$\mathrm{KOH}$ & $\mathrm{K}:+0.35$ & $\mathrm{O}:+0.31$ & $\mathrm{H}:+0.05$ & Total: +0.71 & -655 \\
\hline $\mathrm{NaCl}$ & $\mathrm{Na}:+0.13$ & $\mathrm{Cl}:+0.05$ & & Total: +0.18 & -142 \\
$\mathrm{KCl}$ & $\mathrm{K}:+0.17$ & $\mathrm{Cl}:+0.09$ & & Total: +0.21 & -52 \\
\hline
\end{tabular}

(a)

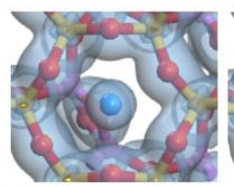

(g)

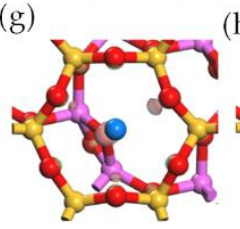

(b)

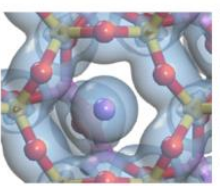

(c)

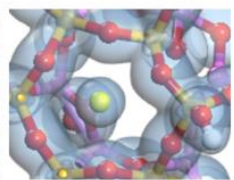

(i) (d)
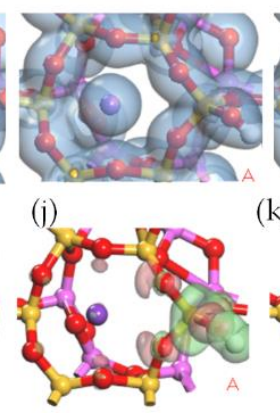

(e)

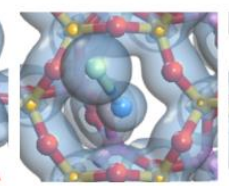

(k)

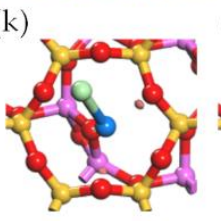

(f)

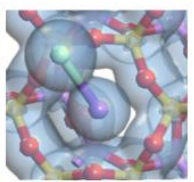

(1)

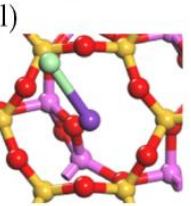

Figure 12. Electron density of single atom adsorptions on Si surface: top view of (a) Na atom adsorption, (b) K atom adsorption, (c) $\mathrm{NaOH}$ adsorption, (d) $\mathrm{KOH}$ adsorption, (e) $\mathrm{NaCl}$ adsorption, and (f) $\mathrm{KCl}$ adsorption. Electron density difference of single atom adsorptions on $\mathrm{Al}$ surface: top view of (g) $\mathrm{Na}$ atom adsorption, (h) $\mathrm{K}$ atom adsorption, (i) $\mathrm{NaOH}$ adsorption, (j) $\mathrm{KOH}$ adsorption, (k) $\mathrm{NaCl}$ adsorption, and (1) $\mathrm{KCl}$ adsorption. 


\section{Discussion}

\subsection{Comparison with Experimental Data}

The adsorption of heavy metals and alkali metals at high temperature consists of not only the surface adsorption but also the inward diffusion [27,29]. No experimental data could be used to compare with calculation data directly. Therefore, the comparison of the experimental data and the calculation data were discussed conservatively. The experimental studies on the metal oxide and hydroxide adsorption by kaolinite were carried out by Wendt et al. who developed the aerosol size fractionation method (ASFM) to detect the reactions between $\mathrm{PbO} / \mathrm{CdO} / \mathrm{NaOH}$ and kaolinite powder in an $18 \mathrm{~kW}$ vertical combustor [12,21,22,42]. The capture efficiency of $\mathrm{PbO}$ vapor was close to that of $\mathrm{NaOH}$ vapor and higher than that of $\mathrm{CdO}$ vapor at $1160{ }^{\circ} \mathrm{C}$; however, all these efficiencies turned to close to each other at $1280{ }^{\circ} \mathrm{C}[12,22,42]$. Wendt et al. attributed the difference between $\mathrm{PbO} / \mathrm{NaOH}$ adsorption and $\mathrm{CdO}$ adsorption at lower temperatures to the products melting which helped the diffusion of products to inside of kaolinite and the exposure of unreacted kaolinite to outside [12,42]. The products of $\mathrm{PbO}$ adsorption and $\mathrm{NaOH}$ adsorption melted at $1160{ }^{\circ} \mathrm{C}$ but the products of $\mathrm{CdO}$ adsorption did not melt until the temperature was up to $1280^{\circ} \mathrm{C}$ [12,42]. According to the adsorption energies in this work, there was no obvious difference in the adsorption of $\mathrm{PbO}, \mathrm{CdO}$, and $\mathrm{NaOH}$. Therefore, the adsorptions of $\mathrm{PbO}, \mathrm{CdO}$, and $\mathrm{NaOH}$ should have less difference in chemical process but more in physical process. Yao et al. compared the capture of $\mathrm{PbCl}_{2}$ and $\mathrm{CdCl}_{2}$ by kaolinite during sewage sludge combustion [43]. At 800-950 ${ }^{\circ} \mathrm{C}$, the capture efficiencies of $\mathrm{PbCl}_{2}$ was higher than that of $\mathrm{CdCl}_{2}$, agreeing with the higher adsorption energy of $\mathrm{PbCl}_{2}$ than that of $\mathrm{CdCl}_{2}$ in this work. In this view, it is possible to use adsorption energy to evaluate the chemical adsorption process of heavy metals and alkali metals vapor by kaolinite.

It is a pity that no available data about the adsorption of $\mathrm{K}$ and its compounds were found so that the discussion combining with experimental data and calculation data was absent here. In this work, the adsorption energies of $\mathrm{K}$ and its compounds were always lower than that of $\mathrm{Na}$ and its compounds. Therefore, it is inferred that the adsorption efficiencies of $\mathrm{K}$ and its compound would be weaker than that of $\mathrm{Na}$ and its compounds as well.

\subsection{Effect of Chlorine Metal Capture}

The thermodynamic equilibrium studies indicated that chloride was the main species of $\mathrm{Pb}, \mathrm{Cd}$, $\mathrm{Na}$, and $\mathrm{K}$ in furnace at around $1000^{\circ} \mathrm{C}$ when the solid fuel contained sufficient $\mathrm{Cl}$ [31]. Wendt et al. found that the addition of $\mathrm{Cl}$ depressed the metal capture by kaolinite significantly. Therefore, chloride was more difficult to absorb than oxide or hydroxide by kaolinite. The much lower adsorption energies of chlorides than those of oxides and hydroxide in this work supported this experimental conclusion. Moreover, there was no $\mathrm{Cl}$ in the products of metal chloride adsorption, so the process of $\mathrm{Cl}$ release should follow the chloride adsorption $[3,23,29]$. The lower adsorption energy and the $\mathrm{Cl}$ release process would be the main reason for low capture efficiency of chlorides. According to the thermodynamic equilibrium calculation, higher temperature causes less metal chlorides and more metal oxides during combustion [31]. Therefore, the high temperature can enhance the metal capture by kaolinite through not only the increase of reaction rate and the promotion of products melting but also the transformation of chlorides to oxides.

\subsection{Effect of Reducing Atmosphere on Metal Capture}

The atmosphere mentioned here indicates the oxidizing atmosphere and the reducing atmosphere. In the reducing atmosphere, some heavy metals such as $\mathrm{Pb}$ and $\mathrm{Cd}$ were supposed to be the elementary substance vapor according to the experimental research and the thermodynamic equilibrium calculation [4,31]. The metal adsorption in reducing atmosphere and the elementary metal vapor adsorption by kaolinite has not been reported yet. The calculation results in this work indicated that $\mathrm{Pb}$ vapor adsorption was possible because the $\mathrm{Pb}$ atom adsorption energy was as high as $-224 \mathrm{~kJ} / \mathrm{mol}$, 
however, $\mathrm{Cd}$ vapor adsorption was impossible because the adsorption energy was physical. During the combustion, some local areas in furnace are at reducing atmosphere, moreover, the solid fuel inside or surrounding are at reducing atmosphere. Thus, the presence of elementary $\mathrm{Pb}$ vapor was possible and a new adsorption path was proposed. During combustion, kaolinite adsorbed elementary $\mathrm{Pb}$ vapor first at reducing atmosphere, and then the adsorption was oxidized in an oxidizing atmosphere, turning to $\mathrm{PbO}$ adsorption which was much more stable than elementary $\mathrm{Pb}$ adsorption.

\subsection{Competitive Adsorption of Multicomponents}

Gale et al. found that $\mathrm{PbO}$ and $\mathrm{CdO}$ could improve each other's capture efficiency by enhancing the eutectic-melt during $\mathrm{CdO}$ adsorption by kaolinite and avoiding the excessive-melt during $\mathrm{PbO}$ adsorption by kaolinite [44]. According to similar adsorption energy of $\mathrm{PbO}$ and $\mathrm{CdO}$, the competition between their adsorption would be equal in chemistry. Gale et al. found that the presence of $\mathrm{NaOH}$ inhibited $\mathrm{PbO}$ capture and the presence of $\mathrm{PbO}$ had no effect on $\mathrm{NaOH}$ adsorption [44]. They considered $\mathrm{NaOH}$ to have a slightly higher reaction rate than $\mathrm{PbO}$, thus achieving capture before the most significant sorbent deactivation occurs [44]. The calculation results supported this opinion that $\mathrm{NaOH}$ could adsorb on both $\mathrm{Al}$ surface and $\mathrm{Si}$ surface while $\mathrm{PbO}$ could only adsorb on $\mathrm{Al}$ surface. The excessive melt should be induced by $\mathrm{NaOH}$ mainly. Further investigation should be performed to reveal mechanisms of the competitive adsorption.

\section{Conclusions}

The adsorptions of typical heavy metals ( $\mathrm{Pb}$ and $\mathrm{Cd}$ ) and typical alkali metals ( $\mathrm{Na}$ and $\mathrm{K}$ ) by meta-kaolinite were investigated by the DFT calculation. The adsorption energies were obtained and followed the sequence of $\mathrm{NaOH}-\mathrm{Si}$ surface $>\mathrm{KOH}-\mathrm{Si}$ surface $>\mathrm{PbO}-\mathrm{Al}$ surface $\approx \mathrm{CdO}-\mathrm{Al}$ surface $\approx$ $\mathrm{NaOH}-\mathrm{Al}$ surface $>\mathrm{KOH}$-Al surface $>\mathrm{NaCl}$-Al surface $\approx \mathrm{Na}$-Si surface $>\mathrm{Na}$-Al surface $>\mathrm{KCl}-\mathrm{Al}$ surface $>\mathrm{Pb}$-Al surface $>\mathrm{PbCl}_{2}$-Al surface $>\mathrm{CdCl}_{2}$-Al surface $\approx \mathrm{K}$-Si surface $\approx \mathrm{PbCl}$-Al surface $>\mathrm{K}$-Al surface $>\mathrm{CdCl}-\mathrm{Al}$ surface $>\mathrm{NaCl}-\mathrm{Si}$ surface $>\mathrm{KCl}$-Si surface $>\mathrm{Cd}$-Al surface. All the adsorptions on $\mathrm{Al}$ surface were chemical except for the $\mathrm{Cd}$ atom adsorption. The adsorptions of metal atoms were due to the attraction from the raised $\mathrm{O}$ atoms in $\mathrm{Al}$ surface. The adsorptions of metal oxide and hydroxide were due to the attraction from the $\mathrm{Al}$ atoms to the $\mathrm{O}$ atom. The adsorptions of metal chloride were due to the attraction from the $\mathrm{Al}$ atoms to the $\mathrm{Cl}$ atoms. Although $\mathrm{Pb}, \mathrm{Cd}$, and their compounds did not adsorb on Si surface, $\mathrm{Na}, \mathrm{K}$, and their compounds did. The $\mathrm{Cl}$ atom in $\mathrm{NaCl}$ and $\mathrm{KCl}$ inhibited adsorption on Si surface; however, it was in favor of adsorption on $\mathrm{Al}$ surface. The strong adsorptions of $\mathrm{NaOH}$ and $\mathrm{KOH}$ were due to their decomposition and the products of $\mathrm{OH}$.

Author Contributions: X.W. designed the research and wrote the manuscript. M.C. and C.L. calculated all the cases. C.B., J.Z., and Y.H. provided additional ideas and revised the manuscript. C.Z. provided funding for the manuscript.

Funding: This research was funded by the National Key Research and Development Program of China (2018YFB0605102).

Acknowledgments: Special thanks to the College of Chemistry and Materials Science of Nanjing Normal University for the use of DFT calculation program.

Conflicts of Interest: The authors declare no conflict of interest.

\section{References}

1. Ober, J.A. Mineral Commodity Summaries; USGS: Reston, VA, USA, 2018; p. 204.

2. Haldar, P.K.; Mithia, S.; Mukherjee, K.; Dhabarde, N.R.; Bansal, E.; Phulwari, P.; Kumar, A.; Kesh, S.; Maity, S. The Effect of Kaolinite Content of China Clay on the Reactivity of Limestone Calcined Clay Cement; Springer: Dordrecht, The Netherlands, 2018; pp. 195-199.

3. Zhang, X.; Liu, H.; Xing, H.; Li, H.; Hu, H.; Li, A.; Yao, H. Improved sodium adsorption by modified kaolinite at high temperature using intercalation-exfoliation method. Fuel 2017, 191, 198-203. [CrossRef] 
4. Wang, X.; Huang, Y.; Liu, C.; Zhang, S.; Wang, Y.; Piao, G. Dynamic volatilization behavior of Pb and Cd during fixed bed waste incineration: Effect of chlorine and calcium oxide. Fuel 2017, 192, 1-9. [CrossRef]

5. Wang, X.Y.; Huang, Y.J.; Zhong, Z.P.; Yan, Y.P.; Niu, M.M.; Wang, Y.X. Control of inhalable particulate lead emission from incinerator using kaolin in two addition modes. Fuel Process. Technol. 2014, 119, 228-235. [CrossRef]

6. Yi, H.; Hao, J.; Duan, L.; Tang, X.; Ning, P.; Li, X. Fine particle and trace element emissions from an anthracite coal-fired power plant equipped with a bag-house in China. Fuel 2008, 87, 2050-2057. [CrossRef]

7. Emission Characteristics of $\mathrm{PM}_{10}$ and Trace Elements from a Coal-Fired Power Plant Equipped with ESP. Available online: https:/ /www.researchgate.net/profile/Qiang_Yao4/publication/265655593_Emission_ Characteristics_of_PM_10_and_Trace_Elements_from_A_Coalfired_Power_Plant_Equipped_with_ESP / links /54eb05520cf2f7aa4d58c18d.pdf (accessed on 30 September 2018).

8. Xu, M.; Yan, R.; Zheng, C.; Qiao, Y.; Han, J.; Sheng, C. Status of trace element emission in a coal combustion process: A review. Fuel Process. Technol. 2004, 85, 215-237. [CrossRef]

9. Linak, W.P.; Wendt, J.O.L. Toxic metal emissions from incineration-Mechanisms and control. Prog. Energy Combust. Sci. 1993, 19, 145-185. [CrossRef]

10. Karatza, D.; Lancia, A.; Prisciandaro, M.; Musmarra, D.; Di Celso, G.M. Influence of oxygen on adsorption of elemental mercury vapors onto activated carbon. Fuel 2013, 111, 485-491. [CrossRef]

11. Yao, H.; Naruse, I. Using sorbents to control heavy metals and particulate matter emission during solid fuel combustion. Particuology 2009, 7, 477-482. [CrossRef]

12. Wendt, J.O.L.; Lee, S.J. High-temperature sorbents for $\mathrm{Hg}, \mathrm{Cd}, \mathrm{Pb}$, and other trace metals: Mechanisms and applications. Fuel 2010, 89, 894-903. [CrossRef]

13. Huang, Y.; Wang, X.; Liu, C.; Wang, Y.; Dong, L. Kaolinite induced control of particulate lead and cadmium emissions during fluidized bed waste incineration. Asia-Pac. J. Chem. Eng. 2017, 12, 321-331. [CrossRef]

14. Dou, B.L.; Shen, W.Q.; Gao, J.S.; Sha, X.Z. Adsorption of alkali metal vapor from high-temperature coal-derived gas by solid sorbents. Fuel Process. Technol. 2003, 82, 51-60. [CrossRef]

15. Davidsson, K.O.; Steenari, B.M.; Eskilsson, D. Kaolin addition during biomass combustion in a 35 MW circulating fluidized-bed boiler. Energy Fuel 2007, 21, 1959-1966. [CrossRef]

16. Aho, M. Reduction of chlorine deposition in FB boilers with aluminium-containing additives. Fuel 2001, 80, 1943-1951. [CrossRef]

17. Yang, W.; Zhu, Y.; Cheng, W.; Sang, H.; Xu, H.; Yang, H.; Chen, H. Effect of minerals and binders on particulate matter emission from biomass pellets combustion. Appl. Energy 2018, 215, 106-115. [CrossRef]

18. Sun, W.; Liu, X.; Xu, Y.; Zhang, Y.; Chen, D.; Chen, Z.; Xu, M. Effects of the modified kaolin sorbents on the reduction of ultrafine particulate matter $\left(\mathrm{PM}_{0.2}\right)$ emissions during pulverized coal combustion. Fuel 2018, 215, 153-160. [CrossRef]

19. Lee, S.H.D.; Johnson, I. Removal of gaseous alkali metal compounds from hot flue gas by particulate sorbents. J. Eng. Power 1980, 102, 397-402. [CrossRef]

20. Takuwa, T.; Naruse, I. Detailed kinetic and control of alkali metal compounds during coal combustion. Fuel Process. Technol. 2007, 88, 1029-1034. [CrossRef]

21. Davis, S.B.; Wendt, J.O.L. Quantitative analysis of high temperature toxic metal sorption rates using aerosol fractionation. Aerosol Sci. Technol. 2000, 33, 536-543. [CrossRef]

22. Gale, T.K.; Wendt, J.O.L. In-furnace capture of cadmium and other semi-volatile metals by sorbents. Proc. Combust. Inst. 2005, 30, 2999-3007. [CrossRef]

23. Scotto, M.V.; Uberoi, M.; Peterson, T.W.; Shadman, F.; Wendt, J.O.L. Metal capture by sorbents in combustion processes. Fuel Process. Technol. 1994, 39, 357-372. [CrossRef]

24. Uberol, M.; Shadman, F. High-temperature removal of cadmium compounds using solid sorbents. Environ. Sci. Technol. 1991, 25, 1285-1289. [CrossRef]

25. Uberoi, M.; Shadman, F. Sorbents for removal of lead compounds from hot flue-gases. AICHE J. 1990, 36, 307-309. [CrossRef]

26. Uberoi, M.; Shadman, F. Aluminosilicates as potential sorbents for controlling metal emissions. ACS Symp. 1992, 515, 214-222.

27. Wang, X.Y.; Huang, Y.J.; Zhong, Z.P.; Pan, Z.G.; Liu, C.Q. Theoretical investigation of cadmium vapor adsorption on kaolinite surfaces with DFT calculations. Fuel 2016, 166, 333-339. [CrossRef] 
28. Wang, X.; Huang, Y.; Pan, Z.; Wang, Y.; Liu, C. Theoretical investigation of lead vapor adsorption on kaolinite surfaces with DFT calculations. J. Hazard. Mater. 2015, 295, 43-54. [CrossRef] [PubMed]

29. Zhang, Z.; Liu, J.; Yang, Y.; Shen, F.; Zhang, Z. Theoretical investigation of sodium capture mechanism on kaolinite surfaces. Fuel 2018, 234, 318-325. [CrossRef]

30. San Nicolas, R.; Cyr, M.; Escadeillas, G. Characteristics and applications of flash metakaolins. Appl. Clay Sci. 2013, 83, 253-262. [CrossRef]

31. Wang, X.; Huang, Y.; Niu, M.; Wang, Y.; Liu, C. Effect of multi-factors interaction on trace lead equilibrium during municipal solid waste incineration. J. Mater. Cycles Waste Manag. 2016, 18, 287-295. [CrossRef]

32. Poole, D.; Argent, B.B.; Sharifi, V.N.; Swithenbank, J. Prediction of the distribution of alkali and trace elements between the condensed and gaseous phases in a municipal solid waste incinerator. Fuel 2008, 87, 1318-1333. [CrossRef]

33. Liu, S.; Wang, Y.; Yu, L.; Oakey, J. Thermodynamic equilibrium study of trace element transformation during underground coal gasification. Fuel Process. Technol. 2006, 87, 209-215. [CrossRef]

34. Furimsky, E. Characterization of trace element emissions from coal combustion by equilibrium calculations. Fuel Process. Technol. 2000, 63, 29-44. [CrossRef]

35. Glazer, M.P.; Khan, N.A.; De Jong, W.; Spliethoff, H.; Schürmann, H.; Monkhouse, P. Alkali Metals in circulating fluidized bed combustion of biomass and coal: Measurements and chemical equilibrium analysis. Energy Fuel 2005, 19, 1889-1897. [CrossRef]

36. NIST Chemistry WebBook. Available online: http:/ / webbook.nist.gov/chemistry/form-ser.html (accessed on 2 August 2018).

37. Vanderbilt, D. Soft self-consistent pseudopotentials in a generalized eigenvalue formalism. Phys. Rev. B 1990, 41, 7892-7895. [CrossRef]

38. Perdew, J.P.; Wang, Y. Accurate and simple analytic representation of the electron-gas correlation-energy. Phys. Rev. B 1992, 45, 13244-13249. [CrossRef]

39. Pfrommer, B.G.; Côté, M.; Louie, S.G.; Cohen, M.L. Relaxation of crystals with the quasi-newton method. J. Comput. Phys. 1997, 131, 233-240. [CrossRef]

40. Mulliken, R.S. Electronic population analysis on LCAO-MO molecular wave functions. J. Chem. Phys. 1955, 23, 1833-1840. [CrossRef]

41. Lee, S.G.; Choi, J.I.; Koh, W.; Jang, S.S. Adsorption of $\beta$-D-glucose and cellobiose on kaolinite surfaces: Density functional theory (DFT) approach. Appl. Clay Sci. 2013, 71, 73-81. [CrossRef]

42. Gale, T.K.; Wendt, J.O.L. Mechanisms and models describing sodium and lead scavenging by a kaolinite aerosol at high temperatures. Aerosol Sci. Technol. 2003, 37, 865-876. [CrossRef]

43. Yao, H.; Naruse, I. Control of trace metal emissions by sorbents during sewage sludge combustion. Proc. Combust. Inst. 2005, 30, 3009-3016. [CrossRef]

44. Gale, T.K.; Wendt, J.O.L. High-temperature interactions between multiple-metals and kaolinite. Combust. Flame 2002, 131, 299-307. [CrossRef]

(C) 2018 by the authors. Licensee MDPI, Basel, Switzerland. This article is an open access article distributed under the terms and conditions of the Creative Commons Attribution (CC BY) license (http://creativecommons.org/licenses/by/4.0/). 